\title{
Helleborus net necrosis virus: A New Carlavirus Associated with 'Black Death' of Helleborus spp.
}

\author{
K. C. Eastwell, Washington State University Irrigated Agriculture Research and Extension Center and Department \\ of Plant Pathology, Prosser 99350; L. J. du Toit, Washington State University Northwest Research and Extension \\ Center and Department of Plant Pathology, Mt. Vernon 98273; and K. L. Druffel, Department of Plant Pathology, \\ Washington State University, Pullman 99164
}

\begin{abstract}
Eastwell, K. C., du Toit, L. J., and Druffel, K. L. 2009. Helleborus net necrosis virus: A new Carlavirus associated with 'black death' of Helleborus spp. Plant Dis. 93:332-338.

Symptoms of 'black death' were observed on Helleborus spp. in each of three independent nurseries from across the United States. A new virus of the genus Carlavirus was identified in association with this disease. Symptomatic plants contained curved, rod-shaped particles averaging 800 by $17 \mathrm{~nm}$, and yielded predominant bands of double-stranded (ds)RNA corresponding to approximately 9.0, 2.6, and $1.7 \mathrm{kbp}$. Amplification with degenerate primers for carlaviruses yielded a product of approximately $3,000 \mathrm{bp}$ from diseased plants. Complete genomic sequences of two virus isolates were determined. Particle size, dsRNA patterns, genome organization, and sequence were consistent with members of the family Flexiviridae, genus Carlavirus. The name Helleborus net necrosis virus (HeNNV) is proposed for the virus associated with black death of Helleborus spp. in the United States. The sequence of the $3^{\prime}$ terminus of Helleborus mosaic virus (HeMV) (genus Carlavirus) was also determined. Nucleotide sequences of HeNNV and HeMV were only $49 \%$ identical, revealing the distinct nature of these viruses. Assays for other viruses failed to reveal a consistent association of any other virus with black death symptoms. Cucumber mosaic virus was detected in hellebore specimens both with and without distinct black death symptoms.
\end{abstract}

Hellebores are herbaceous perennial plants of the family Ranunculaceae that are highly prized for their flower structures. Several species of hellebore are now widely distributed in ornamental gardens. Plants of this genus are propagated by either division, seed, or micropropagation. The ability to successfully divide plants or propagate plants through micropropagation is highly dependent on the species and clone. Consequently, many commercial plant lines are grown as seedlings produced from parental lines that have a propensity to produce plants with highly valued flower characteristics (6).

A disease of hellebores referred to as 'black death' was reported in continental Europe and the United Kingdom in the early 1990s (22). Symptoms are most commonly found on cultivars and hybrids of Helleborus orientalis and Helleborus $\times$ hybridus but little is known about the susceptibility or tolerance of other hellebores to this disease. The most striking symptom of black death is the appearance of black streaks between veins of leaf blades and on

Corresponding author: K. C. Eastwell

E-mail: keastwell@wsu.edu

Accepted for publication 10 December 2008

doi:10.1094/PDIS-93-4-0332

(c) 2009 The American Phytopathological Society the main stem of the affected plant. The intense black streaks also disfigure the sepals for which these plants are prized. Severely affected plants may die within one season of developing symptoms. The disease is known to spread but the cause of this disease has remained undetermined, although it has been suggested that the etiological agent is viral in nature $(11,14)$. Superficially, symptoms of black death can be confused with those induced by fungal diseases such as black spot, caused by Coniothyrium hellebori, the most common disease of hellebores, or blight caused by Botrytis cinerea (5). The ability to accurately differentiate between causal agents of hellebore diseases is critical for effective implementation of disease management programs.

Previously, there have been relatively few reports of virus diseases associated with Helleborus spp. A symptomless infection of $H$. niger by Helleborus mosaic virus (HeMV; tentative species in the genus Carlavirus; 4) was reported in Germany $(16,17)$. HeMV is serologically related to other Carlavirus spp., including Chrysanthemum virus $B$ (CVB; 4), Helenium virus $S$ (HVS; 4), and Cowpea mild mottle virus (CPMMV; 17). The vast majority of Carlavirus spp. are transmitted nonpersistently by aphids, but there has been no evidence of spread of HeMV in Germany (16). Cucumber mosaic virus (CMV; genus Cucumovirus) occurs in $H$. niger (15) and $H$. foetidus (8), and a ring spot of hellebore was reported to be associated with Broad bean wilt virus (BBWV; genus Fabavirus), an aphid-transmitted spherical virus (15). Tomato ringspot virus (ToRSV; genus Nepovirus) and a phytoplasma have also been detected in hellebores (21). The ring spots and chlorosis associated with the latter pathogens on other Helleborus spp. are not typical of black death expression in $H . \times$ hybridus.

Many of the symptoms previously attributed to black death of hellebores in Europe were consistent with symptoms observed on samples of Helleborus spp. in Washington State in 2000. Preliminary investigations were conducted on symptomatic plants of $H . \times$ hybridus. Standard diagnostic techniques did not reveal plantpathogenic bacteria or fungi associated with the disease. During the course of this study, diseased samples from three independent U.S. nurseries were tested for several viruses previously reported in hellebores. Results were negative for these viruses but a group-specific reverse transcription polymerase chain reaction (RTPCR) for members of the genus Carlavirus (Agdia Inc., Elkhart, IN) yielded amplification products. Sequence analysis of amplicons produced with other group-specific primers (this study) revealed the presence of a Carlavirus-like sequence in diseased samples. In this study, we demonstrated the association of this Carlavirus sp. with black death and its sequence relationship to other Carlavirus spp. We propose the name Helleborus net necrosis virus (HeNNV) for this new virus species.

\section{MATERIALS AND METHODS}

Plant and virus isolate sources. $H . \times$ hybridus specimens expressing symptoms of black death were obtained from three nurseries designated $\mathrm{G}, \mathrm{H}$, and $\mathrm{I}$ (as requested for anonymity). Nursery $\mathrm{G}$ is situated east of the continental divide whereas nurseries $\mathrm{H}$ and $\mathrm{I}$ are located in the western United States. Lyophilized tissue of $H$. niger infected with HeMV was obtained from the DSMZ Plant Virus Collection in Braunschweig, Germany (USDA-APHISPPQ permit no. 25.64665).

Pathogen screening. During the course of this study, leaf samples exhibiting black death symptoms were submitted for serological testing (Agdia Inc. and Washington 
State University ELISA Testing Laboratory, Prosser). Plants were also tested for phytoplasma by PCR using phytoplasma primer pairs $\mathrm{P} 1 / \mathrm{T}_{\text {int }}$ and $\mathrm{P} 1694 / \mathrm{Pc} 399$ (24).

For testing mechanical transmission of the causal agent of black death, plants to be inoculated were maintained in the dark for $24 \mathrm{~h}$ prior to inoculation. Symptomatic leaf tissue was ground in $50 \mathrm{mM} \mathrm{Na} / \mathrm{K}$ $\mathrm{PO}_{4}, \mathrm{pH} 7.2$, with or without the addition of either $0.2 \%$ thioglycolic acid or $1 \%$ nicotine, and plants were inoculated with the aid of 600-grit silicon carbide (Carborundum). After inoculation, plants were maintained in a greenhouse with ambient light and temperatures ranging from 18 to $25^{\circ} \mathrm{C}$ for observation.

Electron microscopy. Symptomatic leaf tissue $(10 \mathrm{mg}$ per $100 \mu \mathrm{l}$ of buffer) was ground in $0.2 \%$ thioglycolic acid in $50 \mathrm{mM}$ $\mathrm{Na} / \mathrm{K}_{-}-\mathrm{PO}_{4}, \mathrm{pH}$ 7.2. A formvar-coated grid was inverted over the extract in a humidified chamber for $10 \mathrm{~min}$, washed with three drops of water, and stained with $1 \%$ phosphotungstic acid, $\mathrm{pH} 8.5$, for $75 \mathrm{~s}$ before wicking away excess liquid. Grids were examined with a JOEL $1200 \mathrm{EX}$ electron microscope.

Double-stranded RNA isolation and analysis. Double-stranded (ds)RNA was analyzed as a means of detecting a broad range of viruses. dsRNA was isolated from $7 \mathrm{~g}$ of frozen plant tissue as described by Morris and Dodds (20), except that cellulose CC-41 (Whatman Inc., Florham Park, NJ) was used for two cycles of chromatography. The final product was incubated with T1 RNase (Applied Biosystems, Foster City, CA) and DNase (RQ DNase 1; Promega Corp., Madison, WI) for $1 \mathrm{~h}$ at $37^{\circ} \mathrm{C}$. Small products of enzyme digestion were removed through a size exclusion membrane (Amicon YM-30; Millipore, Burlington, MA). The retained material was analyzed by agarose electrophoresis and stained with ethidium bromide. In later studies, the dsRNA was transferred to a nylon membrane (GeneScreen; PerkinElmer, Shelton, CT; 10) and virus-specific bands were identified by hybridization to RT-PCR products derived from the coat protein region (primers CPF: 5'-GTTTAA CCTTAGGTTTGCGG-3' and CPR: 5'AAACACACTACACAAAGCACG- $3^{\prime}$ ) and labeled with digoxigenin-11-dUTP (Roche Diagnostics Corp., Indianapolis, IN). Probe preparation and chemiluminescent detection were as per the manufacturer's recommended procedures using alkaline phosphatase labeled antibodies (Roche Diagnostics Corp.).

RNA cloning and sequence analysis. From symptomatic hellebore leaves, RNA was extracted with a commercial phenol and guanidine isothiocyanate mixture (Trizol; Invitrogen, Carlsbad, CA) according to the manufacturer's instructions, and then precipitated with isopropanol. Firststrand cDNA synthesis was initiated with a first-strand primer (5'-TATGACACGCG
TCGACTAGC-(T) $16^{-3^{\prime}}$ ) (this study) using reverse transcriptase (SuperScript II; Invitrogen). The cDNA was diluted and amplified with Taq DNA polymerase (Invitrogen) using the degenerate primer kegdd (5'-GC[A, G, or T]GG[T or G]GATGAT ATG-3'; modified from a primer designed by $\mathrm{S}$. Wyatt, Washington State University, personal communication) and primer AdPr (5'-TATGACACGCGTCGACTAGC$3^{\prime}$; this study). The resulting amplification product (approximately 3,000 bp) was cloned into pCR 2.1 (Invitrogen) and sequenced in both directions using the Sanger dideoxy chain termination sequencing method (23) at the Laboratory for Biotechnology and Bioanalysis (LBB) at Washington State University (Pullman). Additional upstream sequence was generated using primers developed from this product. Inverse PCR, as previously described (9), was used to obtain clones from cDNA near the 5' end of the genome. From this sequence, primers were designed for $5^{\prime}$ rapid amplification of cDNA ends (RACE; Invitrogen). Primer 1681-251c (5'-CAG GAGTGTTGATGACCAGC-3') was used for first-strand synthesis and primer 168266c (5'-GCGCAGATCTTCCTTAATCC$3^{\prime}$ ) was used in conjunction with the manufacturer's 5' RACE primers to obtain an amplification product for cloning and sequence determination. The entire genome of each of two virus isolates, designated G5 (from nursery G) and H6 (from nursery $\mathrm{H}$ ), from plants exhibiting black death symptoms were obtained and assembled using a manual alignment program (Xesee; 7), and deposited in GenBank (accessions FJ196835 and FJ196836, respectively). The sequence of the $3^{\prime}$ portion of a third isolate, designated I6 (from nursery I), was obtained by cloning amplification products obtained with the degenerate primer kegdd as described above. An additional sequence of isolate I6 was obtained by amplification with virus-specific primers designed from sequences of virus isolates H6 and G5, and deposited in GenBank (accession FJ196837).

Total RNA was extracted from lyophilized tissue of $H$. niger infected with HeMV using an RNeasy Plant Mini Kit (Qiagen Inc., Valencia, CA) following the manufacturer's instructions. Clones representing the RNA of this virus were obtained using the first-strand primer for first-strand synthesis, followed by amplification with the kegdd and AdPr primers as described above. The resulting consensus sequence was deposited in GenBank (accession FJ196838). Sequences of other representative Carlavirus spp. were obtained from online databases and compared with sequences derived in this study. The sequences used were Potato virus $M$ (PVM; NC_001361), Coleus vein necrosis virus (CVNV; NC_009764), Potato rough dwarf virus (PRDV; NC_009759), Chrysanthemum virus B (CVB; NC_009087),
Potato virus S (PVS; NC_007289), Narcissus symptomless virus (NSV; NC_008552), Daphne virus S (DVS; NC_008020), Lily symptomless virus (LSV; NC_005138), Blueberry scorch virus (B1ScV; NC_003499), Aconitum latent virus (AcLV; NC_002795), Hop latent virus (HpLV; NC_002552), Phlox virus $S$ (PhlVS; NC_009383), Passiflora latent carlavirus (PLV; NC_008292), Sweet potato chlorotic fleck virus (SPCFV; NC_006550), Narcissus common latent virus (NCLV; NC_008266), Garlic latent virus (GarLV; NC_003557), and Poplar mosaic virus (PopMV; NC_005343). Nucleotide sequences were aligned using Clustal W (25) and XEsee. Phylogenetic analyses were performed using the utilities of Phylip version 3.67 (12). A cladogram of nucleotide sequence data was prepared using neighbor-joining of 1,000 bootstrapped datasets (SEQBOOT, DNAML, and NEIGHBOR), for which Indian citrus ringspot virus (ICRSV; NC_003093), genus Mandarivirus, was used as the outgroup. Consensus tree branches (CONSENS) produced by bootstrap analysis were indicated only if they were supported by greater than $60 \%$ of the trees.

RT-PCR assay. Based on the sequences derived above, a diagnostic assay was developed to assess mechanical transmission of virus isolates from three nurseries. Templates prepared with the RNeasy Plant Mini Kit were amplified in a one-tube RTPCR system (SuperScript III One-Step RTPCR System with Platinum Taq DNA Polymerase; Invitrogen) with primers HCV8484c (5'-GTTTTAGTGGCAACG ACTCC-3') and HCV8109 (5'-TCGGAC GAGAATTGAAGAGG-3'). Thermal cycling conditions consisted of one cycle of $55^{\circ} \mathrm{C}$ for $30 \mathrm{~min} ; 94^{\circ} \mathrm{C}$ for $2 \mathrm{~min}$; then 40 cycles of $94^{\circ} \mathrm{C}$ for $15 \mathrm{~s}, 63^{\circ} \mathrm{C}$ for $2 \mathrm{~min}$, and $68^{\circ} \mathrm{C}$ for $1 \mathrm{~min}$. Products were analyzed by agarose gel electrophoresis.

\section{RESULTS}

Symptoms considered to be the hallmark of black death can be similar to those caused by common fungal diseases of hellebores, but some distinguishing characteristics were evident. The suite of symptoms associated with black death of the plants received from U.S. nurseries included black streaking along leaf veins and mottling of tissues along or between the leaf veins (Fig. 1A). Black lines progressed down the petioles and main stem of the affected plant. Black streaks appeared on the sepals and carpels (Fig. 1B). The new growth of affected plants sometimes became severely distorted and stunted. Occasionally, vein clearing preceded the development of black line patterns (Fig. 1A). In contrast, symptoms associated with black spot caused by $C$. hellebori, the most common disease of hellebores (5), were characterized by large, concentric, tan, necrotic rings in which 
pycnidia formed under moist conditions (Fig. 1C). Symptoms of infection of hellebores by $B$. cinerea were distinguished from black death symptoms by necrosis and blackening of the affected tissues, primarily along the margins of leaves, as well as blighting of sepals that typically started at the margins and progressed to general blighting of entire flowers under very wet conditions (Fig. 1D). In addition, sporulation of $B$. cinerea was observed on blighted leaves and flowers under moist conditions.
Extracts from black-death-symptomatic leaves were used in attempts to mechanically transmit viruses associated with these symptoms to herbaceous hosts and to identify the causal agent. Separate extracts were prepared from each of three plants from nursery I to inoculate sets of two plants each of Chenopodium quinoa Willd., pickling cucumber (Cucumis sativus L.), and tobacco (Nicotiana occidentalis L.) that are indicators of a broad range of viruses, including those of the genera Nepovirus and Tobamovirus. No symptoms were evident after 3 weeks, an incubation period during which viruses of these genera typically show symptoms on these indicator hosts, thereby suggesting that members of the genera were not transmitted from the symptomatic hellebores.

Additional broad-spectrum techniques were performed to provide basic information about viruses that may be present in the black death symptomatic tissue. Examination of leaf extracts of two blackdeath-symptomatic plants from nursery $\mathrm{G}$

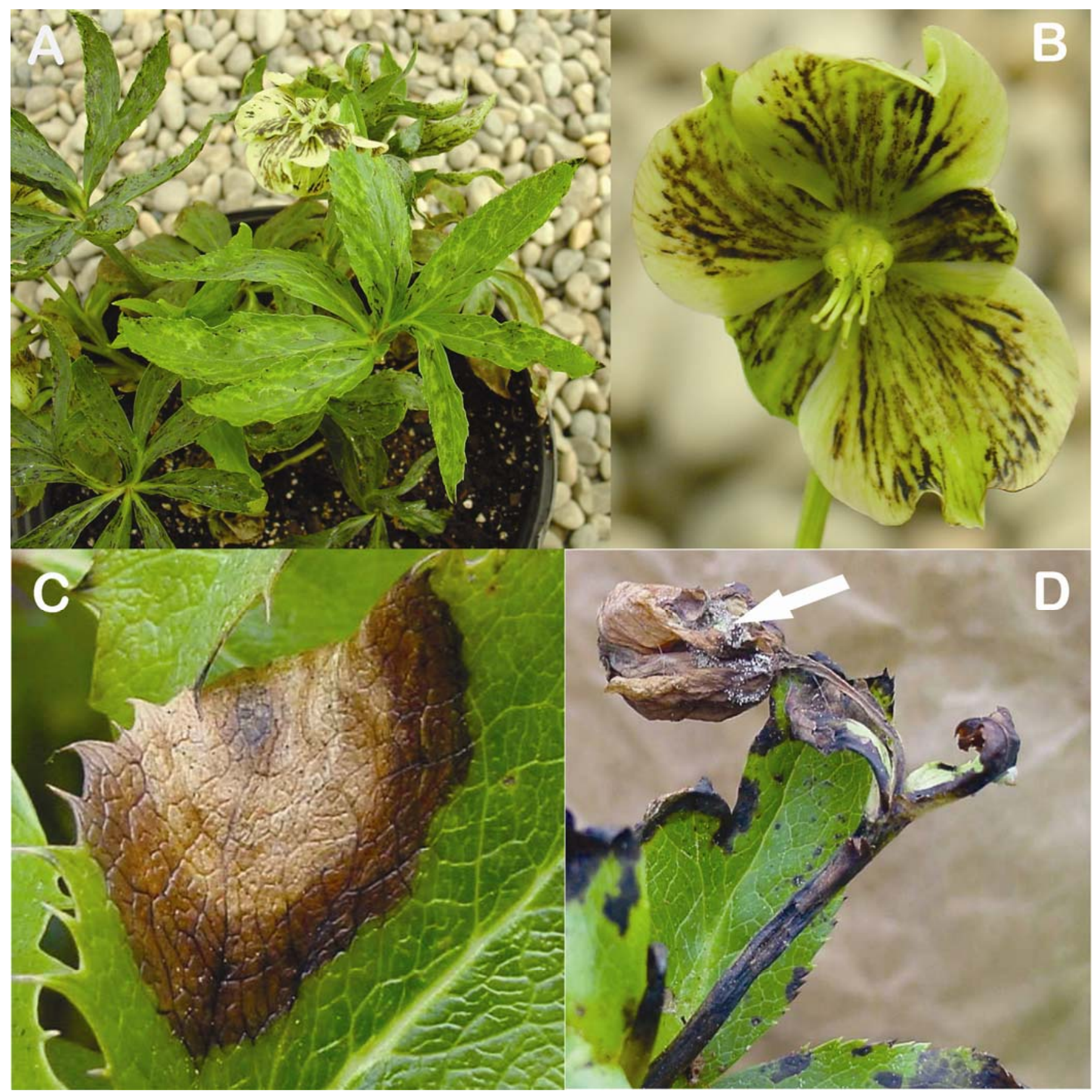

Fig. 1. Symptoms of diseases of hellebores. A, Helleborus $\times$ hybridus exhibiting symptoms of black death, including black lines on leaves and stems. On some seedlings, the line patterns on leaves first appear as vein-clearing followed by discoloration and darkening to characteristic black lines. B, Black line patterns also develop on sepals, following along veination of the tissue. C, Large ( $3 \mathrm{~cm}$ in diameter) lesion on a leaf of Helleborus argutifolius caused by Coniothyrium hellebori. Note the concentric necrotic rings, toward the center of which numerous small (pinhead size), black pycnidia form under moist conditions. D, Blighting of foliage and a flower of a hellebores plant caused by Botrytis cinerea. Note the gray sporulation of $B$. cinerea (arrow) typically produced during moist conditions. 
by electron microscopy revealed the presence of curved, rod-shaped virus particles with dimensions of approximately 800 by $17 \mathrm{~nm}$ (data not shown). No striations or central core were evident in the particles. In addition, dsRNA was analyzed in the leaf extracts. Three predominant bands were observed with sizes of approximately $9.0,2.6$, and $1.7 \mathrm{kbp}$ relative to DNA markers (Fig. 2). The association of the 2.6 and $1.7 \mathrm{kbp}$ bands with HeNNV was subsequently verified by hybridization with digoxigenin-labeled probes (data not shown) produced by RT-PCR using virusspecific primers.

During the course of this investigation, leaf samples exhibiting black death symp-

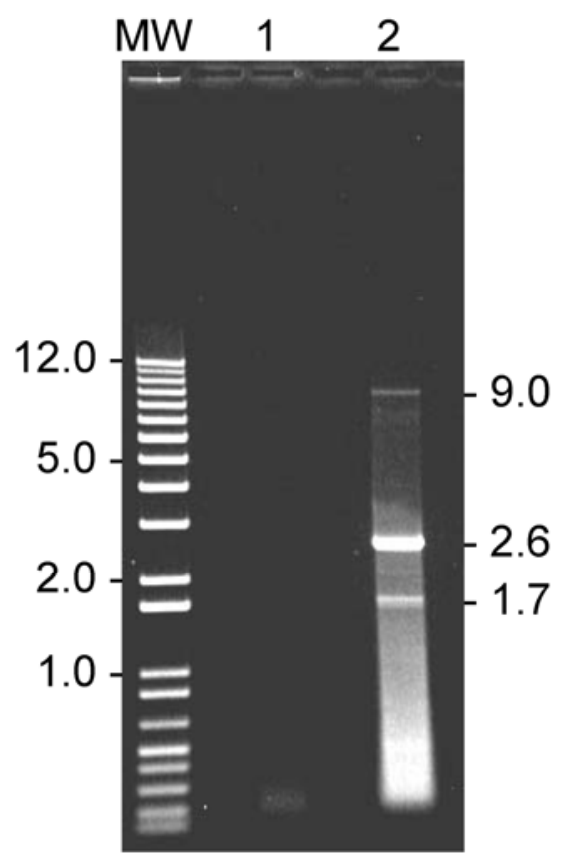

Fig. 2. Double-stranded RNA (dsRNA) isolated from infected Helleborus $\times$ hybridus exhibiting symptoms of black death. The presence of dsRNA in plants is suggestive of infection by an RNAcontaining virus. Asymptomatic plants did not yield detectable amounts of dsRNA in this assay (lane 1). The dsRNA from plants exhibiting black death (lane 2) consisted of three prominent high molecular weight dsRNA bands corresponding to approximate sizes of 9.0, 2.6, and $1.7 \mathrm{kbp}$. Ethidium bromide-stained bands after agarose gel electrophoresis are shown relative to migration of DNA markers (lane MW: $1 \mathrm{~kb}$ plus DNA ladder, Invitrogen). Inferred size of the bands are indicated in kilobase pairs. toms from each of three different nurseries were subjected to serological testing in an effort to identify the virus causing the disease. None of the samples yielded positive enzyme-linked immunosorbent assay (ELISA) results for any of the following viruses (numbers indicate the number of plants tested for that virus): from the genus Tospovirus, Impatiens necrotic spot virus $(n=7)$ and Tomato spotted wilt virus $(n=$ 7); from the genus Alfamovirus, Alfalfa mosaic virus $(n=17)$; from the genus Ilarvirus, Tobacco streak virus $(n=4)$; from the genus Nepovirus, Tomato ringspot virus $(n=1)$ and Tobacco ringspot virus $(n=4)$; from the genus Tobamovirus, Tomato mosaic virus $(n=1)$ and Tobacco mosaic virus $(n=1)$; from the genus $\mathrm{Cu}$ cumovirus, Tomato aspermy virus $(n=4)$; from the genus Carlavirus, Chrysanthemum virus $B(n=18)$; and from the genus Fabavirus, Broad bean wilt virus $(n=8)$. Seven symptomatic plants were tested with the POTY group specific monoclonal antibody (Agdia Inc.), and all yielded negative ELISA results. Additionally, 20 plants with symptoms of black death and 14 plants without black death symptoms but displaying varying degrees of vein clearing and mottling were tested serologically for CMV. One plant exhibiting black death symptoms and eight plants not displaying black death symptoms were positive in the assay for CMV. Thus, there was no positive correlation between the presence of CMV and black death symptoms. Ten symptomatic plants were tested for phytoplasma but none yielded positive PCR results. Five black-death-symptomatic plants were submitted for a Carlavirus groupspecific RT-PCR test (Agdia Inc.) and all five samples yielded positive results.

In total, the above data were consistent with the presence of viruses of the family Flexiviridae in the hellebore samples with black death symptoms. Therefore, the role of Carlavirus spp. in causing black death symptoms was examined further. RT-PCR with degenerate primers designed to react with members of the genera Carlavirus and Potexvirus was applied to extracts from symptomatic and asymptomatic plants. Samples from each of three nurseries yielded positive reactions from symptomatic plants (17 of 17 symptomatic plants) but no products of the predicted size were produced from extracts of asymptomatic plants (0 of 7 asymptomatic plants). Reaction products were sequenced to provide additional information about the targeted virus. Amplicons consisted of approximately 3,030 bp plus a variable number of As and the AdPr primer. The unique portions of the amplified sequences were used to search GenBank using the BLASTN algorithm (2). This revealed significant nucleotide sequence similarity (bit scores $>140$ ) but not identity to several viruses in the genus Carlavirus. Comparison of the sequences obtained from each of the three nurseries revealed two distinct virus genotypes associated with plants that had symptoms of black death. Subsequently, the entire genomic sequence of two isolates (G5 and H6) and the $3^{\prime}$ region of a third isolate (H6) were determined. The virus represented by these sequences is referred to as HeNNV in this study.

Once HeNNV had been identified as the possible causal agent of black death in diseased hellebores, an RT-PCR assay was developed to aid exploration for potential alternate hosts of the virus. In all, 8 to 12 plants of each test species were inoculated as described above. Sets of test plants consisted of Chenopodium quinoa, C. capitatum L., pickling cucumber (Cucumis sativus L.), pumpkin (Cucurbita pepo L. cv. Small Sugar Pumpkin), and tobacco ( $N$. occidentalis L., $N$. edwardsonii L., and $N$. tabacum cv. White Burley). Test plants of the family Ranunculaceae included hellebore seedlings from nursery I, larkspur (Consolida ajacis L. cvs. Frosted Skies and Blue Spires), and petunia (Petunia $\times$ hybrida cv. Blue viola). Plants were observed for 4 weeks after inoculation but no symptoms developed during this time. Leaves that developed after inoculation were collected from each plant and assayed by RT-PCR. No amplicons of the predicted size (376 nucleotides [nt]) were observed from extracts of any of the inoculated plants, whereas extracts of the hellebores that were the sources of inocula yielded positive RT-PCR results. Mechanically inoculated hellebore seedlings were retained for an entire growing season and retested by RT-PCR. No symptoms were observed in the second season and RT-PCR results were negative, suggesting that HeNNV is either not mechanically transmitted or mechanically transmitted with difficulty.

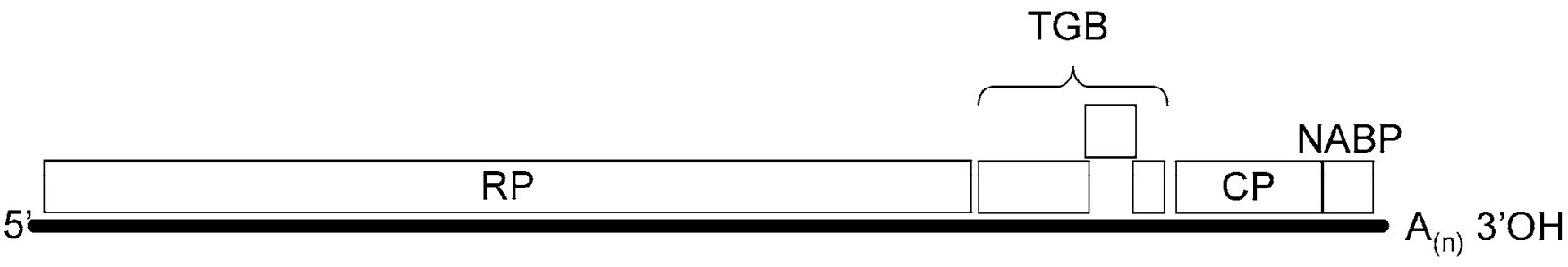

Fig. 3. Genome of Helleborus net necrosis virus (HeNNV) presented six open reading frames (ORFs) that were similar in size, orientation, and sequence to those of members of the genus Carlavirus. Potential ORFs are numbered and identified according to function based on analogy to ORFs of other members of the genus Carlavirus: $\mathrm{RP}=$ replicase, $\mathrm{TBG}=$ triple gene block, $\mathrm{CP}=$ capsid protein, and $\mathrm{NABP}=$ nucleic acid binding protein . 
The molecular relationship of HeNNV to other Carlavirus spp. was explored further by first determining the entire genomic sequence of HeNNV. The length of the complete genomes of isolate G5 and H6 were 8,542 and 8,541 nt plus the 3'(A) $\mathrm{n}$ tail, respectively. The sequences of virus isolates $\mathrm{G} 5$ and $\mathrm{H} 6$ each contained six potential open reading frames (ORFs), all in the same coding sense of the RNA molecule. The sizes and number of ORFs were consistent with that predicted for members of the genus Carlavirus (Fig. 3). Comparison of putative protein sequences to the conserved domain database $(13,18)$ revealed strong similarities to domains expressed in the genome of Carlavirus spp. The 5'-most ORF of HeNNV-G5 (ORF I) had the potential to encode a protein of 1,956 amino acids with a predicted molecular mass of $221.0 \mathrm{kDa}$ and a sequence homologous to Carlavirus proteins with replicase activity. Adjacent to the putative replicase sequence was located a series of three ORFs (ORFs II, III, and IV) typical of the triple gene block (TGB) configuration of some viruses within the family Flexiviridae, including the genera

Table 1. Nucleotide sequence identity of coding sequences and their putative protein products of $\mathrm{Hel}$ leborus mosaic virus (HeMV) and three isolates of Helleborus net necrosis virus (HeNNV)a

\begin{tabular}{|c|c|c|c|c|}
\hline \multirow[b]{2}{*}{ Virus isolate, ORF } & \multicolumn{4}{|c|}{ Virus isolate } \\
\hline & HeNNV-G5 & HeNNV-H6 & HeNNV-I6 & HeMV \\
\hline \multicolumn{5}{|l|}{$\overline{\text { HeNNV-G5 }}$} \\
\hline 5' UTR & $\ldots$ & 100 & & $\ldots$ \\
\hline I RP & $\ldots$ & 80 & $82^{\mathrm{b}}$ & $68^{b}$ \\
\hline II TGB 1 & $\ldots$ & 79 & 79 & 42 \\
\hline III TGB 2 & $\ldots$ & 81 & 81 & 50 \\
\hline IV TGB 3 & $\ldots$ & 79 & 80 & 30 \\
\hline V CP & $\ldots$ & 83 & 84 & 48 \\
\hline VI NABP & $\ldots$ & 91 & 90 & 31 \\
\hline 3' UTR & $\ldots$ & 80 & 80 & 49 \\
\hline \multicolumn{5}{|l|}{ HeNNV-H6 } \\
\hline I RP & 93 & $\ldots$ & $98^{\mathrm{b}}$ & $67^{b}$ \\
\hline II TGB 1 & 84 & $\ldots$ & 98 & 42 \\
\hline III TGB 2 & 88 & $\ldots$ & 99 & 51 \\
\hline IV TGB 3 & 87 & $\ldots$ & 98 & 28 \\
\hline V CP & 97 & $\ldots$ & 99 & 49 \\
\hline VI NABP & 93 & $\ldots$ & 99 & 31 \\
\hline 3' UTR & $\mathrm{n} / \mathrm{a}$ & $\ldots$ & 100 & 48 \\
\hline \multicolumn{5}{|l|}{ HeNNV-I6 } \\
\hline I RP & $97^{\mathrm{b}}$ & $99^{\mathrm{b}}$ & $\ldots$ & $67^{b}$ \\
\hline II TGB 1 & 85 & 99 & $\ldots$ & 42 \\
\hline III TGB 2 & 88 & 100 & $\ldots$ & 51 \\
\hline IV TGB 3 & 87 & 97 & $\ldots$ & 26 \\
\hline V CP & 98 & 99 & $\ldots$ & 49 \\
\hline VI NABP & 92 & 99 & $\ldots$ & 31 \\
\hline $3^{\prime}$ UTR & $\mathrm{n} / \mathrm{a}$ & $\mathrm{n} / \mathrm{a}$ & $\cdots$ & 48 \\
\hline \multicolumn{5}{|l|}{$\mathrm{HeMV}$} \\
\hline I RP & $65^{\mathrm{b}}$ & $67^{\mathrm{b}}$ & $67^{\mathrm{b}}$ & $\ldots$ \\
\hline II TGB 1 & 35 & 36 & 36 & $\ldots$ \\
\hline III TGB 2 & 49 & 52 & 52 & $\ldots$ \\
\hline IV TGB 3 & 41 & 39 & 41 & $\ldots$ \\
\hline V CP & 44 & 44 & 44 & $\ldots$ \\
\hline VI NABP & 15 & 15 & 15 & $\ldots$ \\
\hline 3' UTR & $\mathrm{n} / \mathrm{a}$ & $\mathrm{n} / \mathrm{a}$ & $\mathrm{n} / \mathrm{a}$ & $\ldots$ \\
\hline
\end{tabular}

${ }^{a}$ Six potential open reading frames (ORFs) were identified and include the replicase protein (RP; ORF I); triple gene block proteins (TGB; ORFs II to IV), coat protein (CP; ORF V), and a putative nucleic acid binding protein (NABP; ORF VI). Untranslated regions (UTR) were identified at the $3^{\prime}$ and $5^{\prime}$ terminals of the sequence. The percent nucleotide sequence identities are above the diagonal and the amino acid sequence identities are below the diagonal; $\mathrm{n} / \mathrm{a}=$ not applicable.

${ }^{\mathrm{b}}$ Incomplete coding sequence used in this comparison.

Potexvirus, Mandarivirus, Allexivirus, Carlavirus, and Foveavirus $(1,3,19)$. ORF that of the coat protein and was homogous to sequences of structural proteins of other Carlavirus spp. Sequences of the small ORF VI were consistent with the highly conserved putative nucleic acid binding protein (NABP) located near the $3^{\prime}$ terminus of Carlavirus spp. In addition to contained and ung sequences, the genome $58 \mathrm{nt}$ at the $5^{\prime}$ terminus, a feature shared with other members of the genus Carlavirus. The 3' UTR was $120 \mathrm{nt}$ in length. When 3,268 nt from the $3^{\prime}$ portion of the pared, isolates I6 and H6 were $98 \%$ identical to each other but only $83 \%$ identical to isolate G5. The high degree of nucleotide identity observed across sequences of the belong to the same virugested that they genus Carlavirus (1).

HeMV is a tentative species member of the genus Carlavirus. Nucleotide sequence information was also obtained for the $3^{\prime}$ portion of HeMV following the cloning

336 Plant Disease /Vol. 93 No. 4 strategy outlined above. Comparison of the $3^{\prime}$ sequences of HeNNV isolates G5, H6, and I6 to HeMV revealed 56 to $57 \%$ nucleotide identity. This low level of sequence similarity suggested that HeNNV and HeMV were distinct virus species within the genus Carlavirus. A low level of sequence similarity was also evident in comparison of individual coding nucleotide sequences and putative translation products of HeNNV and HeMV (Table 1). The most similar sequences between HeNNV and HeMV were the partial replicase coding sequences that exhibited 67 to $68 \%$ nucleotide identity and 65 to $67 \%$ amino acid identity.

A cladogram produced with the $3^{\prime}$ terminus of the genomes of Carlavirus spp. revealed a clear association of HeNNV with a clade of Carlavirus spp. that includes PopMV, NSV, and CVNV (Fig. 4); the separation of this clade was well supported by bootstrap analysis. HeMV was associated with a more distantly related population.

To explore the possibility that an additional Carlavirus sp. might be present in plants with black death symptoms, the homogeneity of amplified sequences obtained from infected plants was evaluated. RNA extracts from two symptomatic plants from nursery $G$ were amplified in three independent RT-PCR reactions using degenerate primers as described above. Thirty cloned amplification products were sequenced. All products were homologous to HeNNV; no sequences indicative of a different Carlavirus sp. were detected. This suggested that HeNNV was the only Carlavirus sp. present in these diseased tissues.

\section{DISCUSSION}

Data developed in this study provide strong evidence that the disease known as black death of hellebores is caused by HeNNV. This is demonstrated through studies on plants from three independent sources in the United States. All symptomatic plants examined contained this virus but the virus was not detected in asymptomatic hellebores tested in this study. Multiple amplicons sequenced from diseased plants with degenerate primers consistently yielded sequences representative of HeNNV and no other Carlavirus or Potexvirus sp. HeNNV may be preferentially amplified relative to other Potexvirus or Carlavirus spp. that may cohabitate the diseased tissue: however, analysis of amplicon sequences suggests that this was not the case. Moreover, there is no data to support association of black death with a virus other than HeNNV. dsRNA electrophoretic patterns frequently provide a preliminary means of virus genus identification. In the case of black death, detectable bands were consistent with Carlavirus spp., and no additional bands representative of other virus genera were evident. Involvement of a Carlavirus sp. is further 
supported by observed particle morphology and sequence data.

Sequence data of HeNNV and HeMV suggest that they are archetypal Carlavirus spp. Comparisons of the genomic sequences provide strong evidence for the proposed inclusion of HeNNV and HeMV within the genus Carlavirus. Nucleic acid sequence analyses indicated that the sequences of G5, H6, and I6 represent isolates of the same virus. The high degree of identity of sequences from HeNNV from nurseries $\mathrm{H}$ and I in the United States suggest that these viruses are isolates of the same strain. In contrast, the sequence of HeNNV isolate G5 differed significantly from that of isolates H6 and I6 (Table 1) but remained within the criteria of species demarcation for Carlavirus spp. (1). Thus, based on molecular data, the sequence of isolate G5 represents a strain of HeNNV that is distinct from the strain represented by isolates H6 and I6. Despite this clear distinction, the capsid proteins exhibited significant amino acid sequence identity when the three isolates of HeNNV were compared (Table 1). This suggests that a serological assay may be a valid strategy to

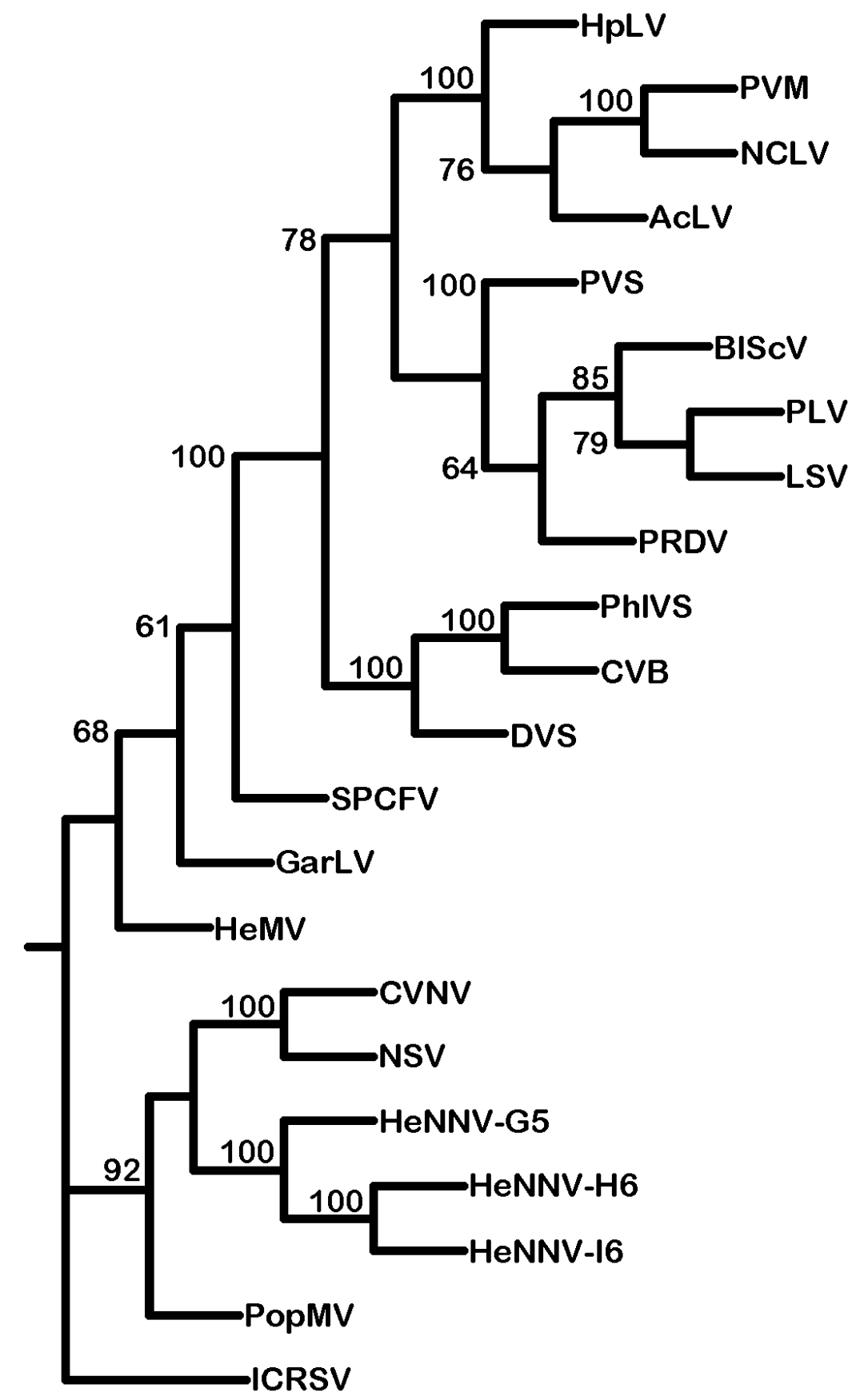

Fig. 4. Phylogenetic analyses illustrating the relationships represented by the RNA $3^{\prime}$ terminus sequences from members of the genus Carlavirus. The rooted cladogram was produced by DNA distance matrix analysis and shows bootstrap reliability estimates $(>60 \%)$ for clades based on approximately 3,000 nucleotides from the $3^{\prime}$ terminus of the virus genomes. The outgroup is Indian citrus ringspot virus (genus Mandarivirus).

pursue for detection of the range of HeNNV isolates used in this study. HeMV, previously reported to occur in hellebores (16), represents a distinct virus from HeNNV and other members of the genus Carlavirus for which sequences have been reported. The low level of predicted amino acid sequence identity (44\%) between the putative capsid proteins of HeNNV and HeMV suggest that these viruses may be differentiated serologically.

Identification of the causal agent of black death is the first critical step in the development of opportunities for disease control. Attempts to identify alternate hosts of HeNNV by mechanical inoculation were unsuccessful in this study. Most Carlavirus spp. have a narrow natural host range (1); therefore, the potential for disease control is promising in plant species that are not widely represented in native flora in the United States. It appears that there may be a long latent period between infection of hellebores by HeNNV and symptom expression. This characteristic would lead to inadvertent introduction of diseased plants through vegetative propagation. Knowledge of the pathogen that causes black death will permit further development of detection methods to aid in preventing introduction of this disease into propagation programs, and in elimination of infected plants should the disease become established in a planting. Additional research is needed to identify potential insect vectors of HeNNV and the possibility of transmission through seed. Natural, nonpersistent aphid transmission is a property of most Carlavirus spp. whereas seed transmission is observed in very few members of this genus, and then only in some hosts. Nurseries and breeding programs that specialize in hellebores frequently produce several species of hellebore in addition to hybrids. The possibility of other Helleborus spp. serving as symptomless carriers of HeNNV should also be explored.

\section{ACKNOWLEDGMENTS}

PPNS no. 0476, Department of Plant Pathology, College of Agricultural, Human, and Natural Resource Sciences Agricultural Research Center Project No. WNP00290, Washington State University, Pullman 99164-6240. This work was also supported in part by Specific Cooperative Agreement no. 59-5358-3-274 with the United States Department of Agriculture-Agricultural Research Service (USDA-ARS), Corvallis, OR. Helleborus mosaic virus was kindly provided under USDAAPHIS-PPQ permit by R. Koenig and supplied through M. Schoenfelder, DSMZ Plant Virus Collection, Mascheroder Weg 1b, 38124 Braunschweig, Germany. We thank S. Lambert and L. Brissey for maintaining plants used in this study; M. Gritsenko and L. Seymour for technical assistance; and T. Unruh (USDA-ARS, Wapato, WA) and H. Pappu (Department of Plant Pathology, Washington State University, Pullman) for reviews of earlier drafts of this manuscript.

\section{LITERATURE CITED}

1. Adams, M. J., Accotto, G. P., Agranovsky, A. A., Bar-Joseph, M., Boscia, D., Brunt, A. A., Candresse, T., Coutts, R. H. A., Dolja, V. V., 
Falk, B. W., Foster, G. D., Gonsalves, D., Jelkmann, W., Karasev, A., Martelli, G. P., Mawassi. M, Milne, R. G., Minafra, A., Namba, S., Rowhani, A., Vetten, H. J., Vishnichenko, V. K., Wisler, G. C., Yoshikawa, N., and Zavriev, S. K. 2005. Flexiviridae. Pages 1089-1124 in: Virus Taxonomy: Eighth Report of the International Committee on Taxonomy of Viruses. C. M. Fauquet, M. A. Mayo, J. Maniloff, U. Desselberger, and L.A. Ball, eds. Elsevier Academic Press, London.

2. Altschul, S. F., Gish, W., Miller, W., Myers, E. W., and Lipman D. J. 1990. Basic local alignment search tool. J. Mol. Biol. 215:403-410.

3. Beck, D. L., Guilford, P. J., Voot, D. M., Andersen, M. T., and Forster, R. L. S. 1991. Triple gene block proteins of white clover mosaic potexvirus are required for transport. Virology 183:695-702.

4. Brunt, A. A. 1996. Helleborus mosaic (?) carlavirus. Page 645 in: Viruses of Plants: Descriptions and Lists from the VIDE Database. A. A. Brunt, K. Crabtree, M. J. Dallwitz, A. J. Gibbs, and L. Watson, eds. CAB International, Wallingford, UK.

5. Burrell, C. C., and Tyler, J. K. 2006. Growing hellebores. Chapter 6, pages 160-185 in: Hellebores, a Comprehensive Guide. Timber Press, Portland, OR.

6. Burrell, C. C., and Tyler, J. K. 2006. Propagating hellebores. Chapter 7, pages 186-206 in: Hellebores, a Comprehensive Guide. Timber Press, Portland, OR.

7. Cabot, E., and Beckenback, A. T. 1989. Simultaneous editing of multiple nucleic acid and protein sequences with Xesee. Comput. Appl. Biosci. 5:233-234.

8. Cardin, L., and Onesto, J. P. 2003. First report of Cucumber mosaic virus in Helleborus foetidus in France and Italy. Plant Dis. 87:1263.

9. Druffel, K., Carson, J. A., Hartney, S., and Hadwiger, L. A. 2005. Inverse PCR to identify
DNA sequence upstream of the pea HMG I/Y open reading frame. Pisum Genet. 37:15-18.

10. Eastwell, K. C., and Bernardy, M. G. 1996. Association of high molecular weight doublestranded RNA with little cherry disease. Can. J. Plant Pathol. 18:203-208.

11. Eastwell, K. C., Druffel, K. L., and du Toit, L. J. 2004. Etiology of the 'black death' disease of Helleborus spp. Page 289 in: Abstracts of the American Society for Virology 23rd Annual Meeting, Montreal, PQ, Canada.

12. Felsenstein, J. 2004. PHYLIP (Phylogeny Inference Package) version 3.66. Distributed by the author. Department of Genome Sciences, University of Washington, Seattle

13. Finn, R. D., Mistry, J., Schuster-Böckler, B., Griffiths-Jones, S., Hollich, V., Lassmann, T., Moxon, S., Marshall, M., Khanna, A., Durbin, R., Eddy, S. R., Sonnhammer, E. L. L., and Bateman, A. 2006. Pfam: clans, web tools and services: Nucleic Acids Res. 34:D247-D251.

14. Henricot, B. 2004. Black death in hellebores: characterization of a virus disease in Helleborus $X$ hybridus. Royal Horticultural Society Science Report 2004, online publication.

15. Kleinhempel, H. 1991. The causal agent of the helleborus ringspot disease. Arch. Phytopathol. Pflanzenschutz 27:415.

16. Koenig, R. 1985. Recently discovered virus or viruslike diseases of ornamentals and their epidemiological significance. Acta Hortic. 164:21-31.

17. Mansour, A., Al-Musa, A., Vetten, H. J., and Lesemann, D. E. 1998. Properties of a cowpea mild mottle virus (CPMMV) isolate from eggplant in Jordan and evidence for biological serological differences between CPMMV isolates from leguminous and solanaceous hosts. J. Phytopathol. (Berl.) 146:539-547.

18. Marchler-Bauer, A., Anderson, J. B., Derbyshire, M. K., DeWeese-Scott, C., Gonzales, N. R., Gwadz, M., Hao, L., He, S., Hurwitz, D. I.,
Jackson, J. D., Ke, Z., Krylov, D., Lanczycki, C. J., Liebert, C. A., Liu, C., Lu, F., Lu, S., Marchler, G. H., Mullokandov, M., Song, J. S., Thanki, N., Yamashita, R. A., Yin, J. J., Zhang, D., and Bryant, S. H. 2007. CDD: a conserved domain database for interactive domain family analysis. Nucleic Acids Res. 35:D237-D240.

19. Memelink., J., van der Vlugt, C. I. M., Linthorst, H. J. M. , Derks, A. F. L. M., Asjes, C. J., and Boll, J. F. 1990. Homologies between the genomes of a carlavirus (lily symptomless virus) and a potexvirus (lily virus $\mathrm{X}$ ) from lily plants. J. Gen. Virol. 71:917-924.

20. Morris, T. J, and Dodds, J. A. 1979. Isolation and analysis of double-stranded RNA from virus infected and fungal tissue. Phytopathology 69:854-858.

21. Navalinskiene, M., Samuitiene, M. and Jomantiene, R. 2003. Identification of Tomato ringspot nepovirus and subgroup 16SrI-A of phytoplasmas infecting hellebore plants in Lithuania. Sodininkyste Ir Darzininkyste (Lithuania) 22:259-268.

22. Rice, G., and Strangman, E. 1993. Pests and diseases. Page 17 in: The Gardener's Guide to Growing Hellebores. David \& Charles, London.

23. Sambrook, J., Fritsch, E. F., and Maniatis, T. 1989. Molecular Cloning: A Laboratory Manual, 2nd ed. Cold Spring Harbor Laboratory Press, Plainview, NY.

24. Skrzeczkowski, L. J., Howell, W. E., Eastwell, K. C., and Cavileer, T. D. 2001. Bacterial sequences interfering in detection of phytoplasma by PCR using primers derived from the ribosomal RNA operon. Acta Hortic. 550:417424.

25. Thompson, J. D., Higgins, D. G., and Gibson, T. J. 1994. CLUSTAL W: Improving the sensitivity of progressive multiple sequence alignment through sequence weighting, positionspecific gap penalties and weight matrix choice. Nucleic Acids Res. 22:4673-4680. 